\title{
Effect of monopalmitic content and temperature on precipitation rate in biodiesel-petroleum diesel blends
}

\author{
Indy Prasetya Girry $^{1}$, Imam Paryanto ${ }^{1}$, Tirto Prakoso $^{2}$, and Misri Gozan ${ }^{1 *}$ \\ ${ }^{1}$ Department of Chemical Engineering, Faculty of Engineering, Universitas Indonesia, Depok \\ 16424, Indonesia \\ ${ }^{2}$ Department of Chemical Engineering, Faculty of Industrial Engineering, Institut Teknologi \\ Bandung, West Jawa, Indonesia.
}

\begin{abstract}
The need for cleaner fuel increases alongside the necessity of reducing greenhouse gas emissions. Biodiesel is considered as one of best options for cleaner energy. However, it has disadvantages due to lower stability, lesser cold flow properties (CFP), and higher viscosity, which are mainly caused by fatty acid type and content. These works investigate CFP of various biodiesel blends B20 \& B30, with the objective on how the monopalmytic as one of the saturated monoglycerides (SMG) content and Temperatures affect the precipitation rate. A set of $100 \mathrm{ml}$ separatory funnels containing various samples were put in refrigerators in controlled-temperature, i.e. $15^{\circ} \mathrm{C} ; 20^{\circ} \mathrm{C}$; and room temperature. The rate of precipitation was observed every day for 2 weeks using $0.8 \mu \mathrm{m}$ membrane filter. Results indicated precipitation rate of B30 was higher than that of B20. As it was expected, the precipitate was taken at the same temperature, $20^{\circ} \mathrm{C}$, resulting in $\mathrm{B} 30$ had more precipitate in the end (37.6 mg) compared to B20 (22.2 mg). The closer to cloud point also indicates the higher rate of precipitation as $4^{\text {th }}$ day $\mathrm{B} 20$ at $15^{\circ} \mathrm{C}(25.4$ $\mathrm{mg})$ compared $4^{\text {th }}$ day B20 at $20^{\circ} \mathrm{C}(19.3 \mathrm{mg})$. The change of crystal from less stable $\alpha$-phase to more stable, less soluble $\beta$-phase is also proven to significantly affect the rate of precipitation.
\end{abstract}

\section{Introduction}

Biodiesel is a fast growing renewable energy that can be produced from animal and plant oil, as well as from oil waste such as cooking oil waste through esterification process (Altaie et al. 2016). The transesterification process transforms the fatty acid in oil into fatty acid methyl ester (FAME). The main composition of biodiesel itself are methyl ester consists of a different type; oleic, linoleic, palmitic. The properties of biodiesel largely depend on its

* Correspondent Author: Email: misrigozan@gmail.com 
composition, and it mostly because of the oil sources. Fatty acid composition affects the cold flow properties (CFP) significantly. Biodiesel freezing point increases as atom carbon in the chain of carbon increases and decreases as double bond increased. Biodiesel that comes from saturated fatty acid has higher Cloud point (CP) and Pour point (PP). Thus Biodiesel from vegetable oil have CP and PP lower from animal oil [1]

Transesterification of triglycerides with alcohol produces alkyl esters (biodiesel) and glycerol. This reaction happened through series of transformation from triacylglycerol to diacylglycerol and monoacylglycerol to eventually become glycerol. In each step, methyl ester is made. In normal optimum condition yield of conversion very high, so that trace from triacylglycerol is very low, however this trace even in very minimum amount affect the biodiesel properties significantly [1]

Biodiesel has its own distinct advantages as it is more safety-renewable energy, nontoxic and better performance on a car than petroleum diesel, and has a lubricant effect [2]. However, until now only $20 \%$ biodiesel- $80 \%$ Petroleum diesel blend (B20) has been allowed to be used in the car without modification. This is due to Cold Flow Properties (CFP) that causes precipitation to form at not just below cloud point $(\mathrm{CP})$ temperature but also above CP [3]. This precipitate leads to the fuel filter and dispenser filter to eventually clogged. This made blend range that allowed only $5-20 \%$ as ruled in ASTM D9675.

The precipitation normally occurs because of following condition: (1) blending biodiesel with petroleum diesel, (2) Transesterification with branched-chain alcohol, (3) Winterization, (4) Chemical additives, (5) Fatty acid modification [4]. Winterization is the most common reason for precipitation. Mainly because of the temperature can go down below cloud point, however The precipitation also occurs above cloud point due to a huge gap between cloud point and final melting point. This happens on high saturated monoglycerides contain between $0.2-0.3 \%$ wt [5]

The formation of precipitate starts with a trace of monoglycerides that unsaturated become a cloud, or change in solution color into milky. At this point it will form metastable crystal. The next step crystal become polymorf and increases in number, bigger in size, and more stable. This stable crystal then creates precipitation in the bottom of the container [6].

This study focused on the precipitation occurs at temperatures above cloud point. The aim of this experiment is to know how the rate of precipitation happened during unstable period and stable period. Monopalmitic is chosen as variation as it affects the CFP significantly [7], and it is abundant in palm-oil feedstock.

\section{Materials and Methods}

\subsection{Characterization of Biodiesel and Petroleum diesel}

Biodiesel that was used are palmitic oil bought from Indonesia. The petroleum diesel was bought from Indonesia. The composition profile of this biodiesel and petroleum diesel was characterized by using Gas Chromatography/Mass Spectrometry.

Biodiesel was added volumetrically to petroleum diesel to obtain B20 and B30. To modify the monopalmitic content, a certain mass of monopalmitic is added to change the monopalmitic contain from around $0.4 \%$ to $0.6 \%$ and $0.8 \%$. Magnetic stirer was used to homogenize the solution at $55^{\circ} \mathrm{C}$ and speed of $1000 \mathrm{rpm}$. Characterisation for biodiesel and petroleum diesel were done on the following ASTM properties: density, kinematic viscosity, cloud point, water and sediment, fame contain, acid number, oxidation stability, aromatic contain, monoglyceride contain, total glycerol, free glycerol.

In order to increase monopalmitic contain, standard equation for concentration are used as below: 


$$
m_{a}=\frac{c \times V \times \rho}{x}
$$

$m_{a}=$ mass of monopalmitic to add $(\mathrm{g})$

$\mathrm{C}=$ Concentration to increase (wt/ $\mathrm{wt} \%)$

$\mathrm{V}=$ Volume of B100 (ml)

$\mathrm{P} \quad=$ Density $(\mathrm{g} / \mathrm{ml})$

\subsection{Beaker Test}

Biodiesel blend consist of B20, B30, and Monopalmitic variation were observed every day for the first week and on $10^{\text {th }}$ and $14^{\text {th }}$ day for the $2^{\text {nd }}$ week. This biodiesel was stored under controlled-refrigerator at temperature of $15^{\circ} \mathrm{C}, 20^{\circ} \mathrm{C}$, and room temperature. Room temperature was ranging between $28-30^{\circ} \mathrm{C}$. The sample then was taken each day to undergo vacuum filtration with membrane filter pores $0,8 \mu$. This method is a modification from Cold Soak Filter Test (CSFT) from ASTM D7501. The standard method from ASTM is for determination of fuel filter blocking potential of biodiesel. The initial method controled biodiesel around $4,5^{\circ} \mathrm{C}$ for 16 hour then filtered using vacuum filter $0,7 \mu \mathrm{m}$. This work changed the temperature to observe how the biodiesel perform under various temperature that is higher than cloud point.

\section{Results and discussion}

\subsection{Characterization result}

Parameters that influence the performance of biodiesel have been analyzed . Tthe cloud point (CPs of B30 was higher than B20. Table 1 shows basic characterization as ruled in ASTM, for the petroleum diesel and biodiesel used in this experiment. Table 2 shows that Monopalmitic and Stearic as monoglycerides that dominant in the sample. As the precipitate contained low Monooleic, it was considered that monooleic has minimum effect on the precipitation.

Table 1 Parameter Analysis for Biodiesel and Petroleum Diesel

\begin{tabular}{|l|c|r|r|}
\hline \multicolumn{1}{|c|}{ Paramater } & Units & Petroleum diesel & Biodiesel \\
\hline Density at 15C & $\mathrm{kg} / \mathrm{m} 3$ & 842.5 & 856.8 \\
\hline Kinematic Viscosity & $\mathrm{mm} 2 / \mathrm{s}$ & 3.35 & 4.51 \\
\hline Cloud Point & ${ }^{\circ} \mathrm{C}$ & 1.7 & $\mathrm{n} . \mathrm{a}$ \\
\hline Water and Sedimen & $\%(\mathrm{wt})$ & $\mathrm{n} . \mathrm{a}$ & 0 \\
\hline Fame Contain & $\%(\mathrm{wt})$ & $\mathrm{n} . \mathrm{a}$ & 09.5 \\
\hline Acid Number & $\mathrm{mg} \mathrm{KOH} / \mathrm{g}$ & $\mathrm{n} . \mathrm{a}$ & 0.34 \\
\hline Oxidation stability & $\mathrm{minutes}$ & $\mathrm{n} . \mathrm{a}$ & 601.5 \\
\hline Aromatic Contain & $\%(\mathrm{wt})$ & 2.54 & $\mathrm{n} . \mathrm{a}$ \\
\hline Monoglyceride contain & $\%(\mathrm{wt})$ & $\mathrm{n} . \mathrm{a}$ & 0.4 \\
\hline Total Glycerol & $\%(\mathrm{wt})$ & $\mathrm{n} . \mathrm{a}$ & 0.1 \\
\hline
\end{tabular}




\begin{tabular}{|l|l|l|l|}
\hline Free Glycerol & $\%(w t)$ & n.a & 0.003 \\
\hline
\end{tabular}

n.a. = data not available

Table 2 Monoglycerides percentage contain

\begin{tabular}{|l|c|}
\hline \multicolumn{1}{|c|}{ Monoglyceride } & Mass Percentage \\
\hline Monopalmitic & 0.357 \\
\hline Monooleic & 0.183 \\
\hline Monostearic & 0.391 \\
\hline
\end{tabular}

Table 3 Paramater Analysis on Biodiesel Blend

\begin{tabular}{|c|c|c|c|c|c|}
\hline \multirow[t]{2}{*}{ Parameter } & \multirow[t]{2}{*}{ Unit } & \multicolumn{2}{|c|}{ Result } & \multirow{2}{*}{$\begin{array}{c}\text { Petroleum } \\
\text { diesel } \\
\text { standard }\end{array}$} & \multirow[t]{2}{*}{ Methods } \\
\hline & & B20 & B30 & & \\
\hline Density at 15 & $\mathrm{~kg} / \mathrm{m} 3$ & 841.1 & 849.1 & $815-870$ & ASTM D4052 \\
\hline Kinematic Viscosity & $\mathrm{Mm} 2 / \mathrm{s}$ & 3.75 & 3.82 & $2-4.5$ & $\begin{array}{r}\text { ASTM } \\
\text { D445 }\end{array}$ \\
\hline Cloud Point & ${ }^{\circ} \mathrm{C}$ & 4.3 & 4.7 & 18 (Max) & ASTM D5773 \\
\hline Water & $\%(\mathrm{wt})$ & 208.11 & 210.31 & 500 (Max) & ASTM D6304 \\
\hline Sediment & $\%(\mathrm{wt})$ & 0 & 0 & 0.01 (Max) & $\begin{array}{r}\text { ASTM } \\
\text { D473 }\end{array}$ \\
\hline Fame Contain & $\%(\mathrm{vol})$ & 19.9 & 29.9 & 20 & ASTM D7806 \\
\hline Acid Number & $\mathrm{mg} \mathrm{KOH} / \mathrm{g}$ & 0.089 & 0.101 & 0.6 & ASTM D664 \\
\hline Oxidation stability & Hour & 36.87 & 36.59 & 35 (Min) & EN 15751 \\
\hline
\end{tabular}

\subsection{Baker test result}

Biodiesel sample was put in separator dunnel then vacuum -filtered on daily schedule . the results were put in $\mathrm{g} / 100 \mathrm{ml}$. Standard monopalmitin contain from biodiesel are around $0,4 \%$. The result shown are for the initial monopalmitin contain and after modification

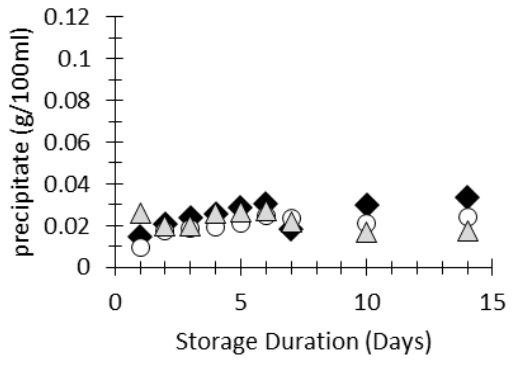

(a)

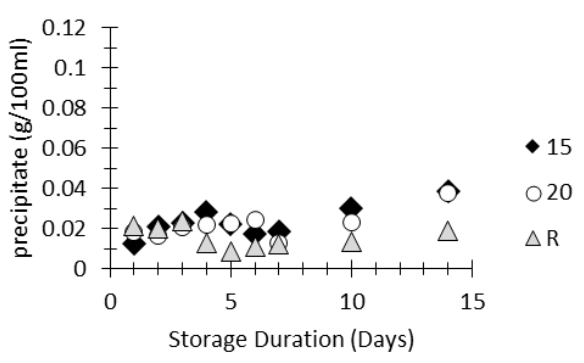

(b) 


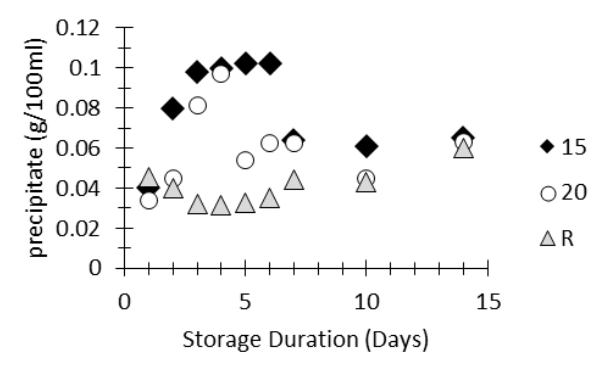

(c)

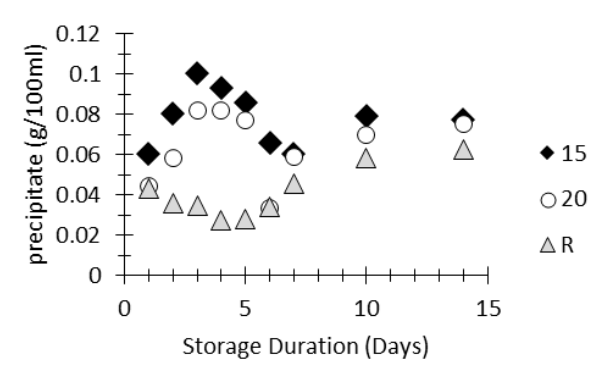

(e)

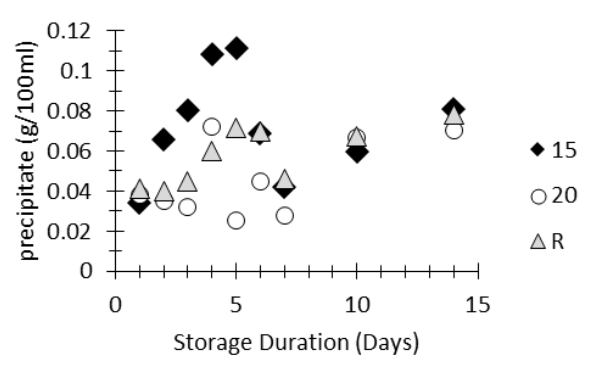

(d)

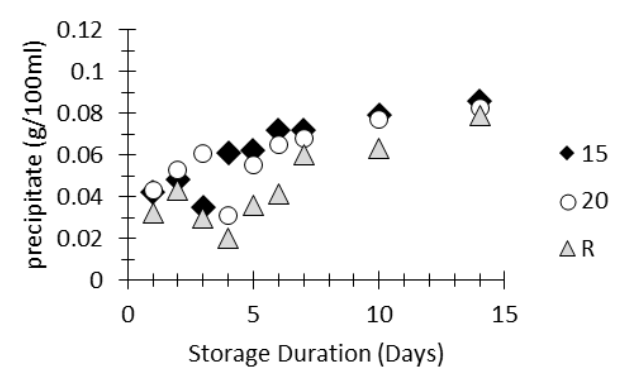

(f)

Fig. 1. The change of formation precipitate at :(a) B20, (b) B30, (c) B20 0,6\%

Monopalmitic, (d) B30 0,6\% Monopalmitic, (e) B20 0,8\% Monopalmitic, (f) B30 $0,8 \%$ Monopalmitic

Between $5 \mathrm{t}^{\mathrm{h}}-7^{\text {th }}$ days at downeard fluctuation of precipitation weight

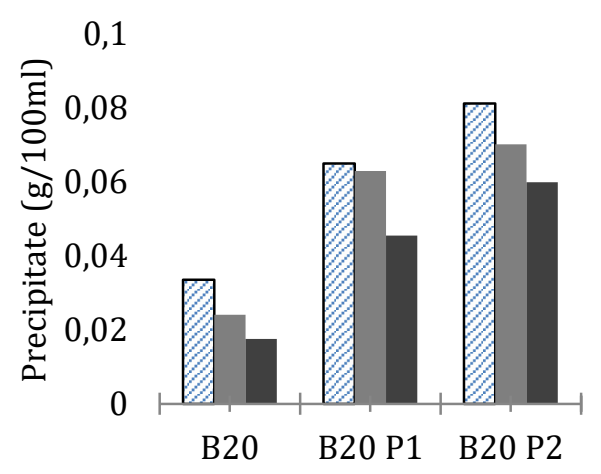

$\square 15^{\circ} \mathrm{C} \quad 20^{\circ} \mathrm{C} \quad$ Room

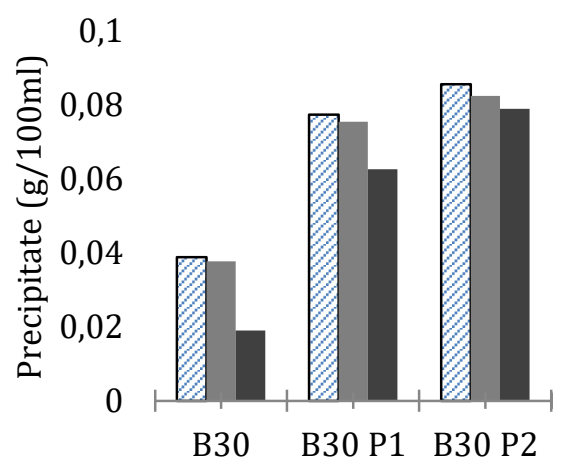

$\because 15^{\circ} \mathrm{C} \quad 20^{\circ} \mathrm{C} \quad$ Room

Fig. 2. Precipitate at the end of $14^{\text {th }}$ day

and precipitation rate. This due to changes in the crystal stability.Differential scanning calorimetry can further explain that in biodiesel, at early start in a cooling process, metastable 
$\alpha$-phase will change into its final form more stable but less soluble $\beta$-phase. This $\beta$-phase also has higher final melting points (FMT), which much effect the precipitate at the last day [8].

Moreover Chupka also found that at low concentration of monopalmitic,, all of the precipitate dissolved during the transformation process. Thus the decreasing of precipitate also affected by this.

Fig 1. Also explain how the change in temperature affect the rate of precipitation. B20 which stored at $15^{\circ} \mathrm{C}$ has higher rate at $\alpha$-phase $(0.003 \mathrm{~g} / 100 \mathrm{ml} /$ day) compared to $\mathrm{B} 20$ stored at $20^{\circ} \mathrm{C}(0.0026 \mathrm{~g} / 100 \mathrm{ml} /$ day $)$. This due to the closer to cloud point $(\mathrm{CP})$, in this experiment between $4-5^{\circ} \mathrm{C}$.

Adding more monopalmitic increase the $\mathrm{CP}$, as $\mathrm{CP}$ affect the precipitation rate, thus if we compare the precipitation rate at $\alpha$-phase at the same temperature $15^{\circ} \mathrm{C}, \mathrm{B} 20$ has lower precipitation $(0.003 \mathrm{~g} / 100 \mathrm{ml} /$ day $) \quad$ compared to $\mathrm{B} 20 \quad 0.8 \%$ Monopalmitic $(0.0137 \mathrm{~g} / 100 \mathrm{ml} /$ day $)$. Same result for B30 $(0.0049 \mathrm{~g} / 100 \mathrm{ml} / \mathrm{day})$ compared to B30 $0.8 \%$ Monopalmitic $(0.0237 \mathrm{~g} / 100 \mathrm{ml} /$ day $)$

Moreover Monopalmitic has reverse micelles structure, this helps rate precipitation to increase as it can lower nucleation energy from monoglyceride. Monopalmitic can then assumed to work like catalyst (Dunn, 2009)

Fig. 5 shows the increae in Monopalmitate precipitate significantly. Adding 0,2\% saturated monopalmitate increase almost $0.05 \mathrm{mg} / 100$ of prexipitation. The B30 and B20 blends show less The B20 and B20 blends show less significant increase compared to the B20 0.4\% Monopalmitic and B20 0.6\% Monopalmitic.

\section{Conclusion}

This CFP study examined the effect of monopalmytic as one of the saturated monoglycerides (SMG) content and temperatures on the precipitation of biodiesel occurred even above cloud point in significant amount. The closer to cloud point the more precipitation produced. After several days, during the 5-7 days the amount of recipitation in the filter decresed, with the concentration on biodiesel-petroleum diesel blend.

\section{Acknowledgment}

Authors are grateful for the financial support provided by Hibah Publikasi Internasional Terindeks untuk Tugas Akhir Mahasiswa (PITTA) through Universitas Indonesia and research facilities provided by Univesitas Indonesia (2477/UN2.R3.1/HKP.05.00/2018).

\section{References}

1. M. Canakci, and H. Sanli, Biodiesel production from various feedstocks and their effects on the fuel properties. J Ind Microbiol Biotechnol 35:431-441 (2008)

2. U.S. Department of Energy, Biodiesel Handling and Use Guide, (2016)

3. G.M. Chupka, L. Fouts, J.A. Lennon, T.L. Alleman, D.A. Daniels, R.L. McCormick, Saturated monoglyceride effects on low-temperature performance of biodiesel blends. Fuel Processing Technology 118 302-309 (2014)

4. O. Edith,R.B. Janius, and R. Yunus, Factors affecting the cold flow behaviour of biodiesel and methods for improvement - A review. Pertanika Journal of Science and Technology, 20(1), 1-14, (2012)

5. G.M. Chupka, L. Fouts, and R.L. McCormick, Effect of low-level impurities on lowtemperature performance properties of biodiesel, Energy Environ. Sci. 5 8734-8742, (2012) 
6. E. Fredrick, I. Foubert, J. De Van Sype and K. Dewettinck,. Influence of monoglycerides on the crystallization behavior of palm oil, Crystal Growth and Design, 8(6), 1833-1839 (2008)

7. M.A.H. Altaie, R.B. Janius, Y.H Taufiq-Yap, U. Rashid, Basic properties of methyl palmitate-diesel blends. Fuel 193 (2017)

8. G.M. Chupka, J. Yanowitz, G. Chiu, T.L. Alleman, and R.L. McCormick, Effect of Saturated Monoglyceride Polymorphism on Low-Temperature Performance of Biodiesel. Energy Fuels 201125 (2010) 